\title{
Geohydrological aspects of importance in the public management of basic water supply services in Merafong City Local Municipality (Carletonville area), South Africa
}

\begin{tabular}{|c|c|}
\hline \multicolumn{2}{|c|}{$\begin{array}{l}\text { Author: } \\
\text { Eric J. Nealer }{ }^{1} \text { (I) }\end{array}$} \\
\hline \multicolumn{2}{|c|}{$\begin{array}{l}\text { Affiliation: } \\
{ }^{1} \text { Department of Public } \\
\text { Administration and } \\
\text { Management, University of } \\
\text { South Africa, Johannesburg, } \\
\text { South Africa }\end{array}$} \\
\hline \multicolumn{2}{|c|}{$\begin{array}{l}\text { Corresponding author: } \\
\text { Eric Nealer, } \\
\text { nealeej1@unisa.ac.za }\end{array}$} \\
\hline \multicolumn{2}{|c|}{$\begin{array}{l}\text { Dates: } \\
\text { Received: } 11 \text { Feb. } 2019 \\
\text { Accepted: } 17 \text { Oct. } 2019 \\
\text { Published: } 31 \text { Mar. } 2020\end{array}$} \\
\hline \multicolumn{2}{|c|}{$\begin{array}{l}\text { How to cite this article: } \\
\text { Nealer, E.J., 2020, } \\
\text { 'Geohydrological aspects of } \\
\text { importance in the public } \\
\text { management of basic water } \\
\text { supply services in Merafong } \\
\text { City Local Municipality } \\
\text { (Carletonville area), South } \\
\text { Africa', The Journal for } \\
\text { Transdisciplinary Research in } \\
\text { Southern Africa 16(1), a671. } \\
\text { https://doi.org/10.4102/ } \\
\text { td.v16i1.671 }\end{array}$} \\
\hline \multicolumn{2}{|c|}{$\begin{array}{l}\text { Copyright: } \\
\text { (c) 2020. The Authors. } \\
\text { Licensee: AOSIS. This w } \\
\text { is licensed under the } \\
\text { Creative Commons } \\
\text { Attribution License. }\end{array}$} \\
\hline \multicolumn{2}{|l|}{ Read online: } \\
\hline 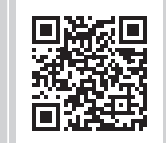 & $\begin{array}{l}\text { Scan this QR } \\
\text { code with your } \\
\text { smart phone or } \\
\text { mobile device } \\
\text { to read online. }\end{array}$ \\
\hline
\end{tabular}

Carletonville is a gold-mining town in western Gauteng province, South Africa, and is located in the Merafong City Local Municipality's geographical area of responsibility. It is one of the richest gold-producing areas in the world but unfortunately the current state of the town's infrastructure is in shambles and the environment is in a pitiful state because of human activities that have caused massive physical changes. Geohydrological aspects such as complex geology and the compartmentalisation of the groundwater into seven areas separated by syenite dykes, of which five have been dewatered to facilitate the gold-mining, have made it the research area of choice. Unfortunately, this led to the formation of hundreds of new sinkholes between the towns of Westonaria and Carletonville and eventually the evacuation of the old town of Bank, abandoning the area and declaring it unsuitable for human settlements. To try and identify possible reasons for this unfortunate state of the human-induced environmental change all along the Wonderfontein Spruit draining the area, the author using a comprehensive literature review, study of geological maps and databases as well as through data collection and semi-structured interviews with selected role-players and stakeholders identified basic essential geographical, geohydrological, organisational and municipal management aspects of significance for consideration. These steps were all a part of an attempt to improve the nature and extent of basic water-, sanitation-, human settlements- and environmental management in the Westonaria, Carletonville and Khutsong areas.

Keywords: community participation; dolomite rock; geohydrology; municipal management; basic water; sanitation service.

\section{Introduction}

Carletonville is a gold-mining town situated on the western side of Gauteng province, South Africa, and borders on the North West province. It is one of the richest gold-producing areas in the world (Treasure Route Association n.d.:online). Carletonville was originally an unplanned settlement established between 1937 and 1957, as various companies laid their gold-mining claims. On 01 July 1959, it attained the Town Council status. It is currently a part of the Merafong City Local Municipality (hereafter referred to as MLM). The area is located approximately $65 \mathrm{~km}$ south-west of Johannesburg and includes the following smaller towns: Blybank, Fochville, Greenspark, Khutsong, Kokosi and Welverdiend. The area is hydrologically drained from the northeast to the southwest by the Wonderfontein Spruit.

Notwithstanding the fact that Carletonville finds itself located in one of the richest gold-producing areas in the world, a drive through the area and superficial personal inspection revealed that the town's roads, storm-water provisioning, potable water reticulation system, sanitation, public housing and the natural- and human-changed environment are not being maintained according to the standards that were until recently still in place and being maintained. The author has been involved in this area, both as a practitioner and as a scientist for 16 years, over a period spanning close to 40 years. These personal observations by the author 2 years ago led him to identify the area for a collaborative community engagement project of the Department of Public Administration and Management, University of South Africa (UNISA).

To add positive action-research value to MLM's basic water-related services in the area, this article specifically reports on a literature review, study of geographical tools such as maps and ortho-photos, compilation of information database and semi-structured interviews with selected role-players and 
stakeholders. These research tools were utilised to identify some basic essential geographical, geohydrological, organisational and municipal management aspects of significance for consideration by the municipal service providers and managers in order to try and strengthen the basic water-, sanitation-, human settlements- and environmental management in the Westonaria and Carletonville areas.

In conclusion, the article reports about important geohydrological related findings made by the author, logical conclusions he came to and some specific, measurable, achievable, realistic and timely (SMART) recommendations that he can make, which the municipality may investigate, consider and implement.

\section{Orientation}

Along the Wonderfontein Spruit, over a distance of $79 \mathrm{~km}$ from immediately south of Krugersdorp to its confluence with the Mooi River near Welverdiend, the environmental disaster and potential mining-created waste land are selfevident. The Westonaria (Randwest Local Municipality) and Carletonville (MLM) areas have become more complicated and problematic with regard to socio-economic and environmental challenges. These include, inter alia, West Rand issues of gold undermined surface areas, geologically underlain by dolomite, sinkholes, acid mine drainage and ineffective corporate social responsibility on the part of mining industries towards the natural and human-changed environment. The area is characterised by, inter alia, dewatered dolomitic compartments, gold-mining and overthe-surface transport (piping) of polluted surface water and effluents from upstream areas such as Krugersdorp, Randfontein, Bekkersdal and some mines. These water sources are collected immediately west of the Donaldson Dam dam-wall, and gravitated along a 1-m diameter pipeline, over approximately $48 \mathrm{~km}$, to be released into the natural flow of the Wonderfontein Spruit immediately west of the dyke, on the northern side of Carletonville. Unfortunately, the water in question is polluted and originates from an officially declared 'abandoned area' (Department of Land Affairs [DLA] 2002). Numerous studies undertaken in the area over a period of more than 50 years have demonstrated the unfavourable environment. The groundwater reserve of the Boskop-Turffontein dolomitic compartment is adversely affected by all the upstream pollution sources. The Boskop Dam, the main water reservoir for the JB Marx Local Municipality (Potchefstroom), is located south of the confluence of the Mooi River and the Wonderfontein Spruit. The groundwater quality of the Gerhard Minnebron spring, located due south of this confluence, is also directly affected by mining activities (north-east of the spring) and the compromised surfacewater inflow into this dolomitic aquifer.

\section{Terminological clarifications}

Dolomite rock is soluble, that is, it dissolves in water. It is composed of mineral dolomite, which is a carbonate of calcium and magnesium rainwater. Percolating groundwater gradually dissolves the rock over time as it seeps through joints, fractures and fault zones in the rock. The term 'dolomitic land' is used to describe areas in South Africa underlain directly or at shallow depth (i.e. up to $100 \mathrm{~m}$ below the ground surface) by dolomite rock (Department of Public Works 2003:online).

The dissolution of the dolomite gives rise to cracks, voids and eventually cave systems through which the groundwater gravitates (usually mimicking the surfacewater flow) on its hydrological journey to an ocean. Soils and plant material covering the rock can collapse into these voids and caves, resulting in catastrophic ground movement on the surface, such as dolines (hollow or basin visible on the ground surface) and in the last instance, sinkholes. To date, in South Africa, 38 people have died in sinkholes that have occurred under, amongst others, sports clubs, factories and homes and financial losses have exceeded R1 billion. More than 1000 sinkholes have occurred on the West Rand, 800 south of Pretoria, Centurion and Atteridgeville and approximately 150 on the East Rand (Department of Public Works 2003:online; Oosthuizen \& Richardson 2011:1).

South African research shows that $96 \%$ of sinkholes and subsidence that have occurred to date were induced by humans, generated by ingress of water from leaking waterbearing infrastructure, poor storm-water management and other factors or because of artificial lowering of the groundwater level. Consequently, intervention through an integrated, comprehensive and pro-active dolomite risk management strategy has the potential to reduce the incidences of ground instability events (sinkhole and subsidence formation) by reducing the likelihood of water gaining entry into the subsurface profile, or controlling dewatering or recharging of the dolomite aquifer (Van Niekerk \& Van der Walt 2006:online).

The first signs of devastating sinkholes in the WestonariaCarletonville area in West Rand, South Africa date back to the 1960s. The West Rand is the area hardest hit by sinkholes, an issue dating back to the discovery of gold more than 120 years ago, with gold mines pumping water out of the underground void. The poorly managed infrastructure creates new sinkholes that endanger service delivery, schools and other public works in the human settlement areas.

\section{Nature of the human-changed environment around Westonaria and Carletonville}

Traveling through the MLM's geographical area of responsibility one is confronted with the horrific state of the natural- and human-changed environment. Tarred streets cluttered with potholes, blocked storm-water channels, no painted lines, or signage and filthy unmaintained sidewalks are the order of the day. In comparison to this depressing 
state of the town environment, the entrances, reception and employee settlement areas of the bigger gold mines in the area exhibit good planning, well-maintained infrastructure and optimum visibility, access and proficiency (see Figure 1)

The following aspects indicated in Figure 1 are worth noting:

- The two municipal areas are geologically underlain by dolomitic rock (see the legend in the figure in which the dolomite underlain area is indicated with the $45^{\circ}$ angle lined shading).

- The geology and subsequent geohydrology of the area are very complex because of, amongst other reasons, the natural underground 'compartmentalisation' in the dolomite by syenite dykes into seven separate compartments and the fact that five of them have been dewatered by gold mines. This practice was initiated to maintain the groundwater level at such a level so as to enable mining to continue effectively and safely.

- The Wonderfontein Spruit rises immediately south of Krugersdorp and is the natural conduit of the continental surface-water divide located to the northeast of the research area. This stream flows through the area in a south-westerly direction, where it merges with the Mooi River, flowing in a southerly direction to meet the Vaal
River at Kromdraai and eventually flows into the Orange River, finally draining into the Atlantic Ocean.

- The surface water in this part of the catchment is artificially collected and diverted into a 1-m diameter (ø) pipeline, from immediately west of the Donaldson Dam up to the downstream side of the syenite dyke of the Oberholzer compartment, north of Carletonville. This surface-water stream diversion is unique and transports water over a distance of approximately $48 \mathrm{~km}$ to allow subsurface mining to continue safely in the area.

- Gold mines (operating and closed ones) occur at approximately 20 locations in the area and are indicated with a mine shaft sign in the figure.

- The area (especially that located across the dewatered dolomite compartments) is riddled with sinkholes (indicated with 'blotchy' dots in Figure 1) and a large area between Westonaria and Carletonville has been declared 'abandoned because of sinkhole occurrence'.

- The N14 national main road from Johannesburg to Potchefstroom passes the area on its south-eastern side.

- The main 'N1' railway line from Johannesburg to Potchefstroom stretches through the area crossing right across the above-mentioned 'abandoned' area from east to west.

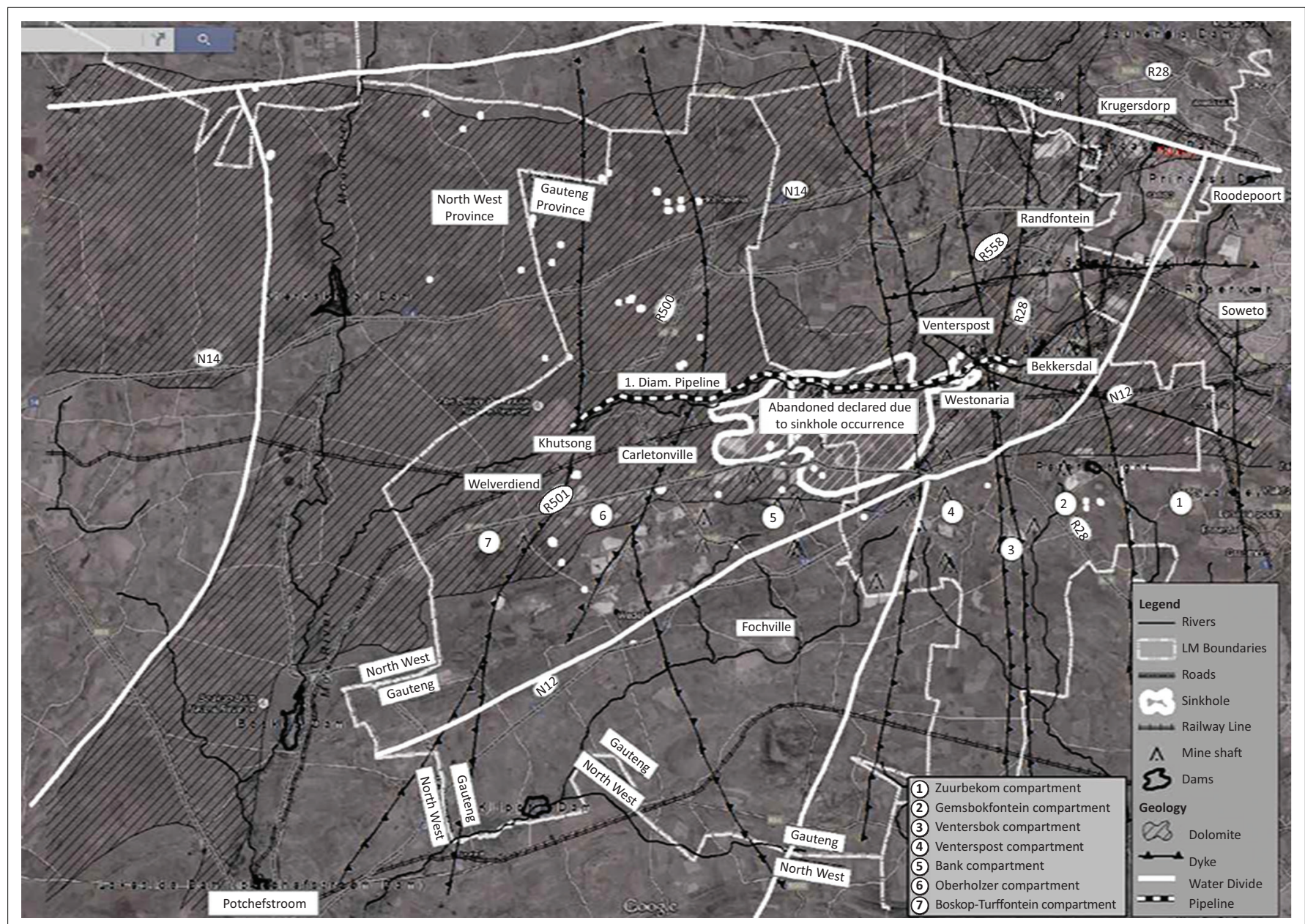

Source: GPM Consultants, 2018, Locality map of the Westonaria and Merafong city local municipality areas, GPM Consultants, Centurion. FIGURE 1: Locality map of the Westonaria and Merafong City Local Municipality areas. 
- No signage is used in the area to warn road- and railway transport users about the dangers of ground surface subsidences, cracks and sinkholes in the immediate surroundings.

- The western boundary of the MLM coincides with the delimiting provincial boundary between Gauteng and North West provinces.

When the gold mines in the Westonaria area came into existence during the 1930s, the mining works, at very deep depths ranging from $2000 \mathrm{~m}$ to more than $3000 \mathrm{~m}$, unfortunately got flooded by the consistent inflow of groundwater. The mines then (prior to the 1960s) obtained permission through Water Abstraction Licenses from the then Department of Water Affairs (now Water and Sanitation) to pump out (abstract) the water and actually dewater the 'dyked-in' compartments and to seal (plug) any inflows of water so that the underground mining works could take place in a dryer and safer work environment.

Unfortunately, this mining strategy and subsequent organisational arrangements had a disastrous effect on the physical- and human-changed environment in that ground surface subsidences and cracks appeared and sinkholes fell in (New York Times 1964:online). Huge areas had to be vacated completely (e.g. Bank, Venterspost and Westonaria). Figure 2 shows photographs depicting the horrific state of affairs because of the forming of sinkholes in the dolomite.

The area indicated on the locality map in Figure 1 as 'abandoned declared area because of sinkhole occurrence' is also to be noted.

In trying to identify possible reasons and confirmation for or of the aforementioned state of the physical- and humanchanged environment, the following reported and sourced incidents and manifestations can be identified:

- On Thursday, 27 October 2016, the Merafong City Local Municipality Council voted to declare Khutsong,
Welverdiend and Carletonville a local state of disaster under the Disaster Management Act (Independent Online [IOL] 2016:online). This came as a response to numerous sinkholes in the area destroying water access and waste disposal infrastructure, leaving thousands of residents without access to basic services in the area.

- According to the Council for Geoscience, millions of South Africans live in 50 towns either completely or partly underlain by dolomite. These include parts of Krugersdorp, Potchefstroom, Sasolburg, Vereeniging, Johannesburg and Pretoria (Centurion) (IOL 2016:online).

- More recently, a pipeline linking a reservoir to Khutsong South, Khutsong New Extensions and Welverdiend fell into a sinkhole, leaving an estimated 23802 residents of the MLM stranded without piped water until September 2017.

- 'Currently we have 10 open sinkholes affecting services, which must still be rehabilitated, pending availability of funds', MLM spokesperson Chris Spies said in a statement (IOL 2016:online).

- A visit by The Star newspaper to Hlanganani Primary School near Carletonville confirmed that the ground surface was shifting and slowly separating the foundation from the building. Bodibe, spokesperson for the Gauteng Provincial Department of Education, said that there were historic sinkholes on the school's property, but the sinkholes had since been closed. Bodibe added that other schools might still be impacted by sinkholes (IOL 2016:online):

Given the fact that a substantial portion of Gauteng Province is underlain by dolomite, it stands to reason that a number of buildings including schools are located on dolomite land. Some of these schools were built before dolomite awareness and foundations and wet services therefore do not necessarily comply with the more recent South African National Standards, Bodibe said in the statement. (Olalde 2016:1)

- A Rehabilitation of Sinkholes project is under way in Merafong City Local Municipality to address ageing and leaking infrastructure. Part of the project includes fixing Khutsong's water delivery, a task expected to cost
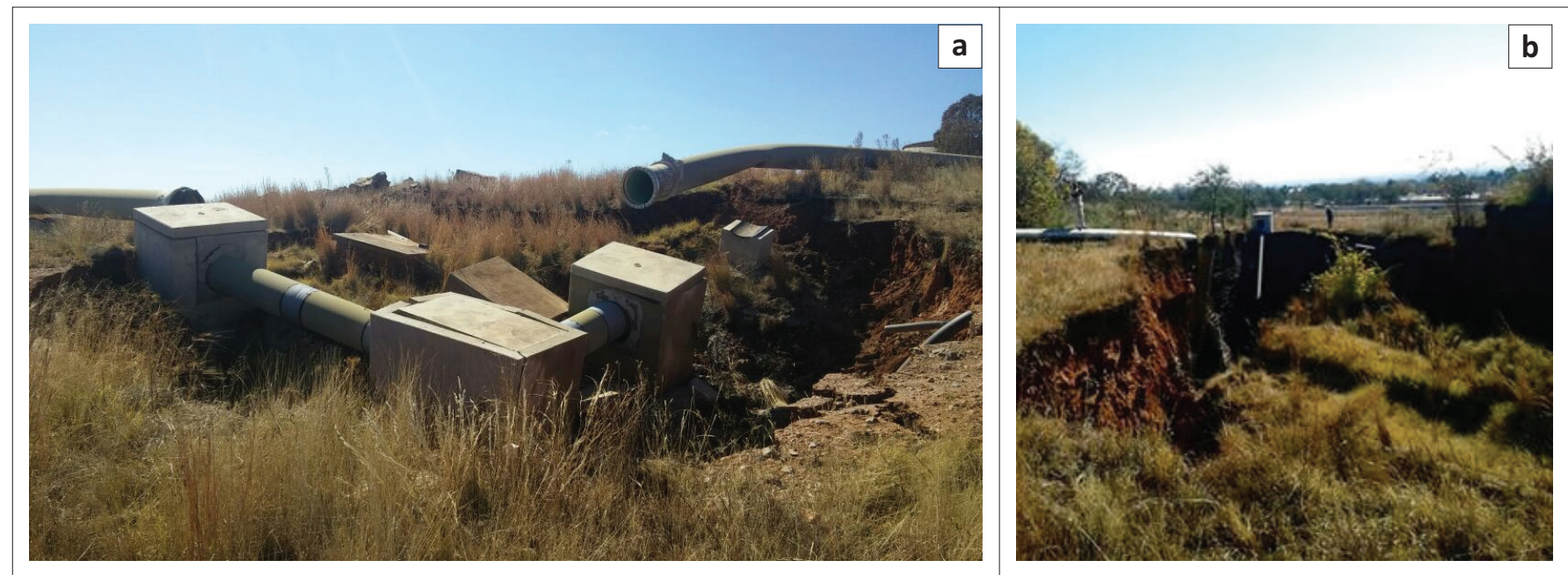

Source: Photos courtesy of E.J. Stoch.

FIGURE 2: Some sinkholes in the Merafong City Local Municipality area. 
R70 million. KBO Projects Construction Company is contracted by the Merafong City Local Municipality to fill sinkholes. General Manager Riemer Wijnja said that impacts to infrastructure were wide-ranging:

We've done a couple of sinkholes that damaged houses and buildings. There's one particular one that's very close to a classroom in a school, and they had to evacuate that classroom, Wijnja said, declining to identify the school. (Olalde 2016:1)

- According to Mr Stoch, an environmental consultant at North-West University, who currently researches the occurrence and forming of new sinkholes, flooding from a silted canal system in the Khutsong area threatens nearby housing developments. As water, including that pumped from mines, overflows the canal, the additional water can cause sinkholes close to houses:

'If you do not manage infrastructure and you allow it to become progressively worse, it gets to a stage of no return when it becomes almost more expensive to maintain it than what it entails to build a completely new system', Stoch said. (E.J. Stoch, pers. comm., 17 June 2018)

- The sinkhole problem is also taking a toll on local businesses. Paulo de Gouveia is a Carletonville business owner who has plans to open a new filling station at the entrance to the town. After he invested in the drilling and permitting necessary to build on dolomite, two large sinkholes formed on his property, most likely caused by leaking water pipes. He will have to push his plans back to next year and most likely re-drill samples in a new area. 'This is all because of bad maintenance. If they walk the line once a week, check that there are no leaks, then we won't be having this problem here', De Gouveia said. 'Rand Water must come to the party and sort us out'. Rand Water declined to comment (IOL 2016:online).

- Sifiso Ngubelanga, a senior scientist from the Council for Geoscience, said:

The Far West Rand area is one of those areas that have been highly influenced by sinkholes. This phenomenon dates back to as early as the 1960s when the mines started the dewatering of the area to access the underlying gold deposits. (IOL 2016:1)

Because of these geohydrological and developmental realities in the Wonderfontein Spruit sub-catchment, the residents of Bekkersdal, Westonaria, Venterspost, Libanon, Carletonville and Khutsong human settlement areas do not have access to usable surface- and groundwater (e.g. water abstracted through boreholes). Their water (raw and potable) is supplied by the Rand Water Board that obtains its water from the Vaal Dam. This fortunate position of the area's inhabitants in terms of easy and ample access to potable water unfortunately might be one of the reasons for them becoming insensitive or non-caring and careless towards the quality or state of the surface- and groundwater in the area. They therefore do not take 'ownership' of a clean and safe physical and humanchanged environment. As a result, the subsequent nature and extent of release of 'treated' sewage and effluent in the natural flow of the Wonderfontein Spruit is no problem of theirs. They seemingly also do not care about the surfaceand groundwater users trying to make a safe living downstream from Carletonville in the Wonderfontein Spruit catchment (including Welverdiend, and small holdings and farms along the Mooi River and the Boskop Dam). This dam is the main water storage facility for the residents of the town of Potchefstroom located downstream.

Some of the major challenges that the residents of this area are confronted with are the following:

- The gold-mining activities taking place $2 \mathrm{~km}-3 \mathrm{~km}$ underground and the ensuing setting off of dynamite and mine blasting, noise, earth tremors and mobilised dust.

- The fact that the underlying dolomite rock formation is being hammered by the mining activities causes cracks in houses, bursting water and sanitation pipes, subsidences in the ground surface and the forming of sinkholes - big enough to swallow a house in its totality.

- Poor intergovernmental relations (IGR) realise amongst, for example, the municipalities, government institutions, private sector enterprises, Non-Governmental Organisations (NGOs), mines and research units of universities as prominent role-players and stakeholders in the area (E.J. Stoch, pers. comm., 17 June 2018).

Judging by, for example, the leading officials of the local municipalities of Westonaria's and Randfontein's very low level of participation on community forums such as the Wonderfontein Spruit (Westonaria and Carletonville) and Mooi River (Potchefstroom) forums, one can only assume that they do not understand the diversity and complexity of the municipal- and environmental health management challenges at hand (J. Janeke, pers. comm., 28 October 2014). These citizen participation forums meet four times a year to discuss common environmental challenges and together try to come up with solutions on how to manage them. At these meetings, the municipal residents unfortunately are present in very small numbers and the following facts have manifested:

- The Department of Water and Sanitation (DWS) acts as a convener of the meetings, usually chairs it and unfortunately dominates the proceedings (the case of 'one of the players also acting as referee').

- The gold-mining companies' personnel sometimes make presentations at a too high and advanced technical level to try and impress and confuse ('fogging technique') the novice attendees (citizen representatives) of the forum meetings.

- The following has been overheard from one of the community attendees: 'by providing nice tea, snacks and lunch I feel as if the host is trying to fill my stomach with nice food and to make me go home empty-headed'.

- Forum meetings usually are called during times on public work-days during which the novice community member cannot be excused from his or her place of work. 
Many feel that they would have been able to attend the meetings more regularly if they were to be called after normal working hours or on a Saturday morning.

- The public media (e.g. Carletonville Herald Newspaper) 'shines in its absence'.

The fact that the natural environment features are landlocked between several municipal boundaries, cover areas of two adjacent provinces and are purely politically and administratively oriented also possibly increases the municipal management complexity in the area. This adds to the perceived absence of effective co-operative governance, integrated water resources management (IWRM), public management of human settlements and effective facilitation of basic municipal services in the area. The nature and extent of IWRM and co-operative governance specifically in the Wonderfontein Spruit and Mooi River sub-catchments between role-players and stakeholders are of a poor standard (M. Liefferink, pers. comm., 06 April 2017).

The fact that the role-players and stakeholders do not communicate effectively (even with the assistance and publicity attempts of the public media [e.g. Carletonville Herald Newspaper]) is depicted by the dilapidated state of streets, sanitation, houses and water reticulation in the area. Figure 3 illustrates the unsafe physical and human-changed environment in the Khutsong Township located in the Merafong City Local Municipality.

In light of the exposition so far of the unfortunate state of the Merafong City Local Municipality's environment, the author in the next three sections identifies and suggests cooperative governance, surface-water catchment management and IWRM as tools to facilitate a positive change in the area.

\section{Co-operative governance}

Co-operative governance is a cross-cutting of various governmental spheres' theme. The South African Constitution of 1996 has established a governance system that forces 'all spheres of government and all organs of state' to co-operate with one another in 'mutual trust and good faith' (Republic of South Africa [RSA] 1996). This should therefore be taking place across and within all public-sector departments regardless of the activity and their location in the project cycle. The National Environmental Management Act (NEMA) and the National Water Act support co-operative governance through, for example, the provision of arrangements, such as catchment management agencies and environmental cooperation agreements (Department of Environmental Affairs [DEA] n.d.:online).

In the facilitation of effective co-operative governance, there is a shift away from the narrow focus of governance to a broader focus, which, inter alia, includes the following:

- process by which governments are selected, monitored and replaced
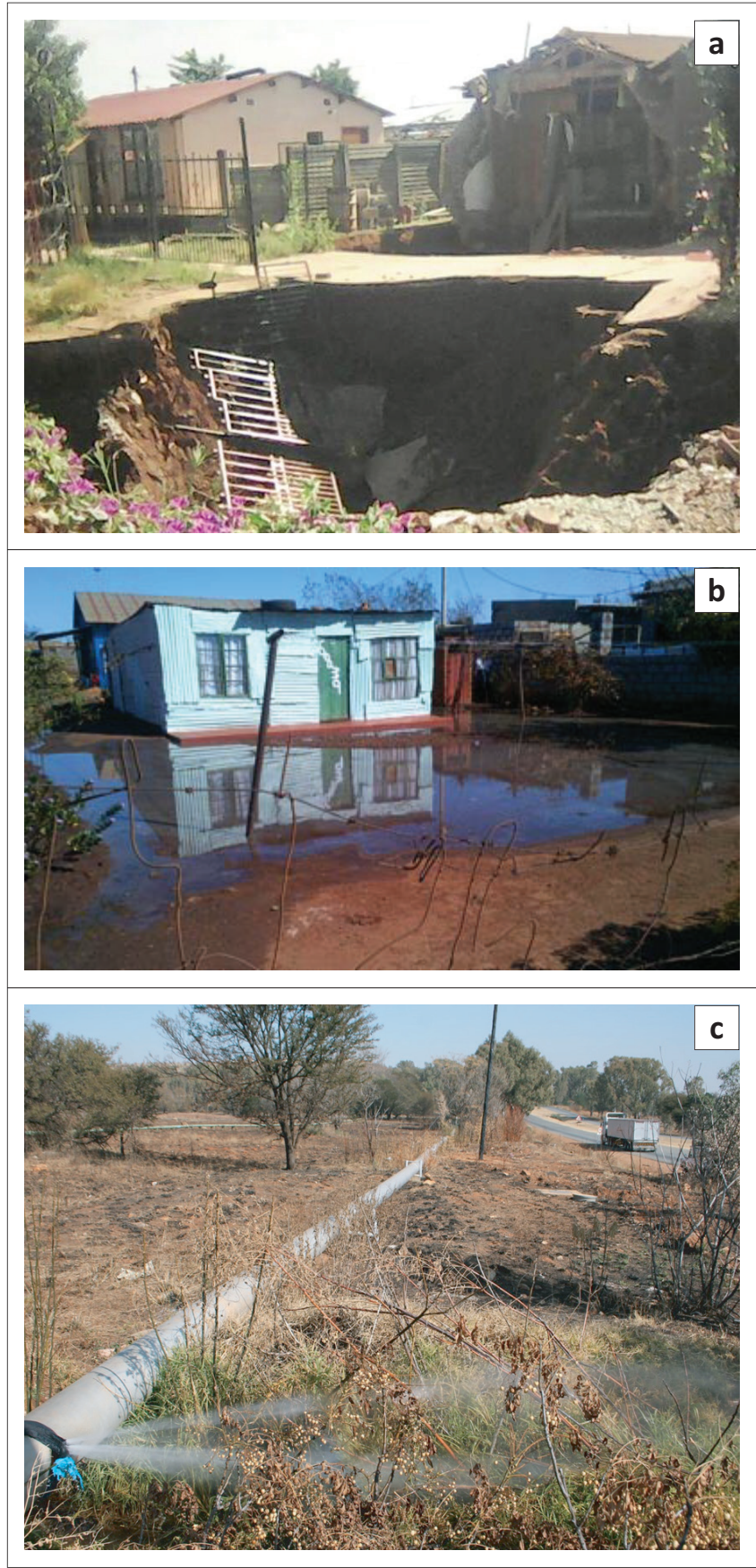

Source: Photos courtesy of E.J. Stoch.

FIGURE 3: Photos depicting the state of destruction in and around the Khutsong area.

- the capacity of the government to effectively formulate and implement sound public policies

- the respect of citizens and the state for the institutions that govern economic, social and environmental interactions (IGR) amongst them (Nealer \& Naude 2011:105).

Furthermore, organisational arrangements such as visibility, access, responsiveness, transparency, participation, equity, effectiveness, efficiency, cost-effectiveness, ethics and environmental sensitivity can also be identified. In terms of these principles, corruption is minimised, the views of minorities are taken into account and the voices of the most vulnerable in society are heard in public decision-making. 
An important key to the aforementioned wider and encompassing focus of co-operative governance is the existence of effective organisational arrangements (internal and external) of which two-way communication is first and foremost. This should lead to higher levels of visibility, transparency, access and willingness of all actors and stakeholders to become involved and to participate in a more active manner towards, inter alia, holistic and synergised group attempts of public service delivery and sustainable development per se.

To make the aforementioned happen, effective public management is essential. Cognisance should especially be taken of the subsequent order in which the individual phases of the public management process in practice unfold, with planning always realising first and control in the last instance. Attention should however be given to the public policymaking and policy implementation activities that have to be executed prior to planning. In terms of the quest to improved co-operative governance and IWRM, the subsequent logical order and role of structuring and organisational arrangements (especially communication) together with the allocation and management of financing, human resources and work procedures should be taken into account. Additional management tools such as information communication technology, performance management (monitoring, reporting and evaluation) and effective representative citizen participation complete the comprehensive definition.

The author's research also revealed that in numerous instances there is a lack of knowledge in municipalities about the following:

- the origin of the water (raw and potable) in the geographical jurisdiction of a municipality;

- the nature and extent of public management of the waterrelated (e.g. potable and used water) services;

- the collection, transport, treatment, release and disposal of the used water;

- the most suitable protocol to follow for human settlement in, for example, a dolomite rock underlain area (Nealer 2015).

Before the management goal of IWRM in a specific geographical area is analysed, the aspect of surface-water catchment must be understood.

\section{Surface-water catchment and divide}

A surface-water catchment is an area of land where surface water from rain, or melting snow or ice converges to a single point at a lower-lying ground surface (metres above mean sea level [mamsl]) elevation (usually the exit of the river basin). These waters then join another waterbody such as a river, lake, reservoir, estuary, wetland, groundwater aquifer or ocean (PediaView 2015:online).

The delimiting line between two adjacent surface-water catchments (e.g. river systems) is called the surface-water divide and stretches along the highest points, for example, a ridge or crest of a spur from where rain water can flow in either direction (U.S. Geological Survey [USGS] 2015:online). The exact location and stretch of a divide are generally delineated from topographic maps based on land elevations indicated with brown contour lines. However, the actual location and stretch of boundaries may be differently demarcated at different times because of map interpretation assumptions or human-induced changes that have occurred since the map was made. It therefore might be necessary to carry out field inspections of the areas in question.

Groundwater watersheds are conceptually similar to surfacewater watersheds because groundwater flows from high points (divides) to low points (outlets, discharge areas). However, the boundaries of surface-water and groundwater watersheds do not always coincide. Groundwater movement occurs in underground located aquifer systems and is subject to: (1) hydraulic properties of the aquifer, (2) input to (recharge) and outflow from (discharge) the aquifer system and (3) geological factors such as rock formations that block the flow of water and tilted formations that create a flow gradient (Minnesota Department of Natural Resources 2015:online).

In the next section, the place and role of IWRM as a strategically important 'vehicle' through which a geo-hydrologically sensitive area like the Wonderfontein Spruit sub-catchment can be developed and managed will be described.

\section{Integrated water resources management}

The reform of potable water services provisioning by means of promulgation of the Water Services Act 108 of 1997 and the National Water Act 36 of 1998 in South Africa has been revolutionary and it started a process of addressing the imbalance that existed in how the national resource was distributed. Water now is recognised as a scarce resource that belongs to all the people of the country and consequently it should be managed in an integrated way for social and economic development including future growth (Fuggle \& Rabie 2005; Riemann, Chimboza \& Fubesi 2012:445). The aforementioned encompasses a sensitivity to careful cognisance and management of 'the aggregate of surrounding objects, conditions, and influences that impact on the life and habits of man or any other organism or collection of organisms' (RSA 1989).

The provision of potable water supply by water services authorities (WSAs) is an important basic service that faces a number of challenges such as the use of outdated infrastructure, lack of skilled and knowledgeable people, improper planning and the booming population that places overt pressure on the demand for service delivery.

The municipalities and government departments of the South African public sector now realise that governments cannot achieve development on their own, and that they need all possible assistance. To make this quest happen, 
an IWRM approach has now been accepted internationally as the way forward for efficient and sustainable development and management of the world's limited water resources and for coping with conflicting demands for water-related services. It is most widely defined by the Global Water Partnership:

$[A] \mathrm{s}$ a process that promotes the coordinated development and management of water, land and related resources, in order to maximise the resultant economic and social welfare in an equitable manner without compromising the sustainability of vital ecosystems. (United Nations [UN] 2008:1)

Furthermore, the de-politicising of water management areas by having them defined by surface-water catchment - rather than political boundaries - is internationally recognised as lending itself to more effective IWRM.

\section{Conclusion and recommendations}

In conclusion, one can understand the importance of utilising a public planning tool such as the surface-water catchment regions of DWS in the day-to-day public planning and organising of a geographical area, such as the Wonderfontein Spruit sub-catchment.

The nature and extent of the demarcated municipal areas are in a state of constant change. The effective utilisation of macro-organising vehicles, such as co-operative governance and with reference to water, IWRM, is of essence. This can be realised by establishing partnerships of effective co-operative governance by means of, inter alia, transdisciplinary research and collaboration as well as strengthening of public policymaking and implementing hands. By becoming more sensitised about the origin of everybody's potable water, the management of it and the disposal of the grey water in the area, the people in authoritative positions as well as the municipal residents might experience an effective capacitation with some basic geohydrological and municipal management knowledge and skills.

So, what can be done to address the challenges identified in a more positive manner and facilitate some positive changes albeit small? The author is of the opinion that through effective co-operative governance and the application of the basics of public sector management by skilled and capacitated municipal officials and politicians together with a committed quest of the community members, effective IWRM can be realised.

To give effect to the aforementioned, the adjustment or alignment of municipalities' geographical areas of responsibility, according to the demarcated surface-water catchment regions of DWS, will assist in the facilitation of more effective IWRM and co-operative governance.

The place and role of the local government sphere in South Africa are demarcated and the necessary legislation and organisational structures are in place. The responsible governmental public service providers must 'just get their act together' and start to implement and execute the numerous governmental policies in terms of more effective and efficient rendering of public services to the citizens of the country. Unfortunately, the committed municipalities are continually experiencing new pressures to deliver a wider variety of usually more complex basic urban public services to citizens who are developing new and more sophisticated needs. This quest to deliver public services in a more effective, efficient, equal, economic and sustainable manner now requires an optimum level of cooperation and integration between the role-players and stakeholders involved. Together, these actors will be able to bring about a positive difference in the nature of basic public service delivery and development in the very dynamic and highly politicised local government sphere.

The occurrence of dolomite rock in a river catchment area requires an urgent new municipal management protocol, which, through effective and efficient co-operative governance and transdisciplinary research, should be acknowledged and managed by the major role-players (i.e. municipality, governmental institutions, mines, universities and NGOs) in the service delivery and regulation of IWRM in the area.

Last but not least, it is recommended that the Merafong City Local Municipality should start to play a much more visible, dominant, leading and managerial role in the whole of the Wonderfontein Spruit and downstream located Mooi River sub-catchments up to, for example, the towns of Westonaria, Carletonville, Fochville, Welverdiend and Potchefstroom.

\section{Acknowledgements Competing interests}

The author has declared that no competing interest exist.

\section{Author's contributions}

I declare that I am the sole author of this research article.

\section{Ethical considerations}

Ethical clearance to conduct the study was obtained from UNISA (REF. PAM 2017-006(CR).

\section{Funding information}

This research received no specific grant from any funding agency in the public, commercial, or not-for-profit sectors.

\section{Data availability statement}

Data sharing is not applicable to this article as no new data were created or analysed in this study.

\section{Disclaimer}

The views and opinions expressed in this article are those of the author and do not necessarily reflect the official policy or position of any affiliated agency of the author. 


\section{References}

Department of Environmental Affairs (DEA), n.d., Environmental impact assessment and management strategy, viewed 16 March 2015, from https://www. environment.gov.za/sites/default/files/docs/eiams_subtheme10.pdf.

Department of Land Affairs (DLA), 2002, 2627BC Westonaria topographical map, DLA, Pretoria.

Department of Public Works, 2003, Public works' manual, viewed 16 November 2016 from https://www.gov.za/sites/www.gov.za/files/dolomitemanual_0.pdf.

Fuggle, R.F. \& Rabie, M.A., 2005, Environmental management in South Africa, Juta \& Co, Ltd., Cape Town.

GPM Consultants, 2018, Locality map of the Westonaria and Merafong city local municipality areas, GPM Consultants, Centurion.

Minnesota Department of Natural Resources, 2015, Surface-water watersheds vs. ground-water watersheds, viewed 16 March 2015, from http://www.dnr.state. mn.us/watersheds/surface_ground.html.

Nealer, E.J., 2015, Catchment management through integrated water resources management and co-operative governance in a municipal area. Inaugural lecture, management and
UNISA, Pretoria.

Nealer, E.J. \& Naude, M., 2011, 'Integrated co-operative governance in the context of sustainable development', The Journal for Transdisciplinary Research in Southern Africa 7(1), 105-118.

New York Times, 1964, Earth holes stir South Africans: Spreading fissures in gold mine area raise fears, viewed 10 July 2018, from https://www.nytimes.com/1964/10/25/ archives/earth-holes-stir-south-africans-spreading-fissures-in-gold-mine.html.
Olalde, M., 2016, Sinkholes - A most significant threat, viewed 16 June 2018, from https://pulitzercenter.org/reporting/south-africa-most-significant-threat.

Oosthuizen, A.C. \& Richardson, S., 2011, Sinkholes and subsidence in South Africa, Council for Geoscience, Pretoria.

PediaView.com, 2015, Drainage basin, viewed 16 April 2015, from https://pediaview. com/openpedia/Drainage_basin.

Republic of South Africa, RSA, 1989, Environment Conservation Act No. 73 of 1989, Government Printer, Pretoria.

Republic of South Africa (RSA), 1996, The Constitution Act 108 of 1996, Government Printer, Pretoria.

Riemann, K., Chimboza, N. \& Fubesi, M., 2012, 'A proposed groundwater management framework for municipalities in South Africa', Water SA 38(3), 445-452. https:// doi.org/10.4314/wsa.v38i3.10

Treasure Route Association, n.d., History Carletonville, viewed 10 July 2018, from http://n12treasureroute.com.

United Nations (UN) Water, 2008, Status report on integrated and water efficiency plans for CSD16, Department for International Development, viewed n.d., from https://www.un.org/waterforlifedecade/iwrm.shtml.

U.S. Geological Survey (USGS), 2015, What is a watershed?, viewed 06 May 2015, from https://water.usgs.gov/edu/watershed.html.

Van Niekerk, H.J. \& Van der Walt, I.J., 2006, Dewatering of the Far West Rand dolomitic area by gold mining activities and subsequent ground instability, viewed 08 August 2018, from https://onlinelibrary.wiley.com/doi/abs/10.1002/ Idr.749. 